\title{
Pre-Service English Teachers' Perspectives Towards Teacher Professionalism: A Narrative Inquiry
}

\author{
Angga Dwi Cahyo Andar Diputro, \& Pratnyawati Nuridi Suwarso \\ Universitas Brawijaya \\ anggaputeraandar@gmail.com; pratnyasuwarso@ub.ac.id
}

\begin{abstract}
How to cite (in APA Style): Diputro, A.D.C.A., \& Suwarso, P.N. (2019). Pre-Service English Teachers' Perspectives Towards Teacher Professionalism: A Narrative Inquiry. Jurnal Pendidikan Bahasa dan Sastra, 20(1), 95-110. DOI: https://doi.org/10.17509/bs_jpbsp.v20i1.25975
\end{abstract}

Article History: Received (14 November 2019); Revised (15 January 2020); Accepted (1 April 2020) Journal homepage: http://ejournal.upi.edu./index.php/BS_JPBSP

\begin{abstract}
Since 2018, there are 2.449 pre-service teachers (PSTs) prepared to be professional teachers. In Indonesia, those PSTs are enrolled in the professional development program called PPG. This research aims to know their perspectives towards teacher professionalism. The method used was the qualitative research method and a narrative inquiry research design. The subjects were ten pre-service English teachers who have different background of studies, experiences, and even interests in becoming teachers. An adapted semi-structured interview guideline and FGD guideline developed from 4 previous studies and the Law Number 14 Year 2005 were employed to collect the data. The results show that the PSTs thought that it has to be more flexible and practical. They also revealed that teacher roles, teacher competencies and teacher professional development program are the determiners of teacher professionalism as what is explained in the law. However, they considered that teacher roles can be supportive aspect towards teacher competencies performed in the classroom. Thus, teacher competencies are the most dominant factor that can influence and determine teacher professionalism.
\end{abstract}

Keywords: pre-service teachers; professionalism; inquiry narrative

\section{Perspektif Guru Bahasa Inggris Pra-Jabatan Menuju Profesionalisme Guru: Kajian Inkuiri Naratif}

\begin{abstract}
Abstrak: Sejak 2018, terdapat 2.449 guru para-jabatan (pre-service-PST) disiapkan untuk menjadi guru profesional. Di Indonesia, PST tersebut terdaftar dalam program pengembangan profesional yang disebut PPG. Penelitian ini bertujuan untuk mengetahui perspektif mereka terhadap profesionalisme guru. Metode yang digunakan adalah metode penelitian kualitatif dan desain penelitian inkuiri naratif. Subjek penelitian adalah sepuluh guru bahasa Inggris prajabatan yang memiliki latar belakang studi yang berbeda, pengalaman, dan bahkan minat untuk menjadi guru. Pedoman wawancara semi-terstruktur dan pedoman FGD yang dikembangkan dari 4 studi sebelumnya dan Undang-Undang Nomor 14 Tahun 2005 digunakan untuk mengumpulkan data. Hasilnya menunjukkan bahwa PST berpikir bahwa itu harus lebih fleksibel dan praktis. Mereka juga mengungkapkan bahwa peran guru, kompetensi guru, dan program pengembangan profesional guru adalah penentu profesionalisme guru seperti yang dijelaskan dalam undang-undang. Namun, mereka menganggap bahwa peran guru dapat menjadi aspek pendukung terhadap kompetensi guru yang dilakukan di kelas. Dengan demikian, kompetensi guru adalah faktor paling dominan yang dapat mempengaruhi dan menentukan profesionalisme guru.
\end{abstract}

Kata kunci: guru pra-jabatan; profesionalisme; kajian inkuiri naratif 


\section{INTRODUCTION}

In the eyes of education, teacher is one of the most important aspects that creates education, and interchangebly, education also creates teacher. In Indonesia, teacher as a profession has become one of the most favorable choices to end up the career with. It is proven by many in-service teachers who are employed in the educational institutions. In addition, there are also many pre-service teachers who are ready to take a step in the world of teacher and education. Nevertheless, their exact total numbers remains uncountable.

Recently, according to the Statistic Presentation Summary published by the Ministry of Education and Culture of Indonesia (2017/2018, p.1-20) about the statistical data of teachers classification towards job statues, it showed that in 2007 approximately 2.3 million teachers were employed teachers (mostly in-service teachers) and 1 million teachers were in the status of non-permanent teachers (including in-service and pre-service teachers). The statistic also claimed that the percentages of the teachers who worked in some educational institutions had not met the institutions and particularly societies' demands (Statistic Presentation Summary, 2017/2018, p. 50). It means that there were still many schools requiring more teachers to fill up the empty positions. It was proven by the lack of teachers in rural areas across Indonesian cities. However. there were many teachers who were non-permanently workers and their availability to work and teach in the educational institutions were still waiting for the vacancy calls. Hence, both in-service and pre-service teachers were the teachers who are still struggling with the future of teachers as profession.

In Indonesia, there are two kinds of teachers classification which are pre-service teachers and in-service teachers. Both classification are employed whether in the state-educational institutions (public schools) or the private-educational institutions (private schools). However, the terms of pre-service and in-service teachers have become a very tricky description, since those people who claimed to have experienced in teaching can not be differed simply as to whether pre-service and inservice teachers. In addition, their experiences and their statues of jobs are different to one another.

Generally, pre-service teachers (PSTs) teach students by their prior beliefs, knowledges, and their roles as a teacher (Kukari \& Ogoba, 2001, p.5). According to Kukari \& Ogoba (2001), PSTs make teaching as a transmission of prescribed knowledge; refers to the teachers' prior beliefs and knowledge on developing the teaching practice to see how significant the teachers apply their professionalism. Moreover, PSTs are still guided and under the supervised teaching program. In-service teachers (ISTs), on the other hand, are the teachers employed under the formal educational institutions (including public and private schools) for a period of time. However, according to Potret Pendidikan Indonesia (2017/2018) shows that the statues of both PSTs and ISTs are still a blury line to the condition permanent and non-permanent employed teachers. Thus, it becomes the concern of the researcher to study this furthermore. Nevertheless, the researcher will be only focused on the PSTs, since the PSTs are the ones who determine the future of ISTs.

In Indonesia, mastering English language become very important and prioritized, since it gives many benneficial impacts. In addtition, English is taught from a very young level of education which is 'Elementary' to the level of a very high education which is 'University'. Hence, many Indonesian pre-service English teachers carried out crucial obligation to educate people. In the same way, preservice English teachers are those who are PSTs in Indonesia. However, PSTs have to face many challenges, one of them is dealing with their professionalism as a teacher. Thus, PSTs need to know and apply a 
simple term but deep within, an unclear notion, called professionalism.

The term of professionalism can not be defined simply by how teachers teach students in the teaching and learning activities done in the classroom, but it is more to how complex and challenging for teachers of achieving professionalism itself. In Indonesia, teacher professionalism is explicitly regulated in the Law Number 14 Year 2005 in which contents explained that teacher roles, teacher competencies, and teacher professional development are the main keys on determining teacher professionalism.

The essence of teacher roles can be derived not only from many previous studies but also from the Law Number 14 Year 2005. According to Wardoyo and Herdiani (2016), the roles of teachers perform directly in the classroom showing how teacher professionalism are implemented. It is portrayed by how teachers able to give good samples of individuals as students supposed to be, and as well as growing people in the social community. In addition, referring the further explanation due to the roles of teacher, according to the Law of Teacher and Lecture Number 14 Year 2005 stated that "Teacher is a professional educator who has major tasks to educate, teach, guide direct, asses and evaluate learners through the formal education". It means that the teachers not only simply transfer knowledge to the students, but also simultaneously shape students' behavior, mindset and identity through the lessons in order to make the students to become better growing persons (Wardoyo \& Herdiani, 2016, p.91).

Moreover, teacher roles are not just simply defined as taking and giving kind of activities, but more into how teachers make individuals able to understand the meaning of learning truly as well as the meaning of life. Through learning, students will learn more about life vividly from the teacher's actions and beliefs (e.g. Kukari \& Ogoba, 2001; Wardoyo \& Herdiani, 2016). In addition, Kukari \& Ogoba (2001) explained that through the teachers' beliefs on something to be followed and avoided, teachers directly will give examples of how students supposed to act. Thus, teacher roles will make people perceive teachers as a complex profession.

Equally, the essence of teacher competencies can be derived not only from many previous studies but also from the Law Number 14 Year 2005. According to Kiymet (2010), teacher is a challenging profession that has certain qualifications and requirements. Usually, each country has their own standards of teacher. For instance competencies is one of the examples that teachers need to have and bring into their profession. In order to improve teachers' performances and to provide better education for the students, teacher competencies are employed to determine 'Good' and 'Professional' teachers. Therefore, standards are to describe what 'Good' and 'Professional' teachers are.

Kiymet (2010) explained that there are 9 (nine) teachers' competencies which teachers have to have in order to be able to conduct proper teaching in both good and professional ways. Based on the Law Numbers 14 Year 2005 Act 8; the act of the National Education Standards likewise explained that there are 4 (four) teachers' competencies which are pedagogical, personality, social and professional. Furthermore, teacher competencies are the key to define their professionalism (Kiymet, 2010, p. 169).

Similarly, the essence of profesional development also can be derived not only from many previous studies but also from the Law Number 14 Year 2005. According to Wardoyo and Herdiani (2016), profesional development in Indonesia is practically a different concept which teacher professionalism supposed to be constructed along with the professional development. Indonesian governments expect to massively create many teachers to have teacher professionalism. In spite of the fact that the government limited teachers to participate in the professional development programs (Wardoyo \& Herdiani, 2016, p. 
91). After all, it shows that government demands are preposterous.

According to the Law Number 14 Year 2015 Act 8, teachers require not only teacher roles and competencies but also academic qualifications such as teachers have to pass certain particular professional development programs in order to acquire the teacher professionalism. Thus, this condition brings teachers to unfavorable positions of getting inconvenient demands from both government to be professional workers and from society to be good teachers. Moreover, complicated requirements dwindled the condition.

In addition, Hargreaves (2000) captured and drew professionalism and its development into four phases which contain certain circumstances that define teachers professionalism. The phases indirectly show teachers professional development stages. Wardoyo and Herdiani (2016) in his research explained that in Indonesia, the professionalism development had reached the level of postmodern phase in which professionalism defined as complex ideas and standards. Moreover, he explained that there was also a relationship between professional development and teachers competencies that further leads his study result into the definition of professionalism. Ultimately, he stated that teachers have to enroll themselves in any professional development programs in order to construct their professionalism successfully (e.g. Hargreaves, 2000, p. 423-438; Wardoyo \& Herdiani, 2016, p. 96).

However, in Indonesia, the government actually has already generated and maintained a program that can improve teachers' professionalism and develop their competencies through a professional teaching development program called PPG (Pendidikan Profesi Guru) or professional teacher certification program. The program aimed to prepare PSTs to in becoming ISTs. The program indirectly also makes PSTs apply the government's standards.

Responding to the teachers professionalism in Indonesia, since the focus of this research is on the PSTs, professional development program called PPG is designated into two kinds of programs which are Prajab and Daljab. According to the Minister of Culture and Education, Prajab is a teacher professional development program designated for freshgraduated teacher students (PSTs), while Daljab is designated for ISTs who have not taken any professional development program yet. Nevertheless, the program is very important for the teachers in constructing their professionalism. Thus, there are many teachers willing to be enrolled in the program.

According to the Minister of Culture and Education's website (2018/2019) shows that there are 2.449 (two thousand four hundred and fourty nine) PSTs prepared to become profesional teachers and ISTs. Those PSTs were enrolled in the PPG program 2018 until 2019 (one year program). According to David and Lisa (2014), teacher professionalism grows up into teachers past and present experiences as well as their future teaching and learning practices plans, yet their baliefs, purposes, and impacts in which refers to their self-efficacy and their concern in teaching. He also explained that 'experience' is the main reason of teachers self pro-claimed themselves professional. In line with David and Lisa (2014), Donna (2011) in her research shows that professional development and experiences can make teachers believe that they are professional depends on their self-efficacy level (e.g. David \& Lisa, 2014; Donna, 2011).

To move along to the reality of teachers' condition towards their professionalism, there is a suprising fact that not all of teachers employed in any educational institution in Indonesia are professional. According to the Indonesian Central Bureau of Statistics (2018) publishing official statistical data of the latest Indonesian bureau showed that teachers profession took the 6th place with about $5,13 \%$ of Indonesian labors worked in the education field. However, from 
$5,13 \%$ around $10 \%$ of teachers were fail to become qualified teachers; referring to the standards in the Law Number 14 Year 2005. According to the Ministry of Education and Culture in Permendiknas RI (Peraturan menteri pendidikan nasional Republik. Indonesia) Number 16 Year 2007 showed that there were 2.700 .000 , a total amount of Indonesian teachers, but about 270.000 teachers were unqualified. Thus, those unqualified teachers can possibly give harmful impacts towards education.

Since teachers profession had lacked $10 \%$ possibilities which lead to unwanted condition towards education, schools need to pay more attention in selecting and hiring teachers. In addition, the teachers who were unqualified may indeed carry out enormous negative effects. For instance, it can be identified by the inadequate teaching performances that eventually trigger students' failure, or simply lead to every possibility cases of unsuccessful teaching, unprofessional teachers and poor education. On the other hand, $90 \%$ of the qualified teachers which are assigned by the government also can trigger some questions in which parameters or indicators of whether those teachers are qualified enough or not are questioned and demanded approved. Furthermore, teachers as educators' purposes are also a homework for the government as well as the teachers themselves.

Regarding the condition in Indonesia related to the teacher as profession and its professionalism, it is clearly hard to be fulfilled by PSTs who do not owned yet the standards of qualified teachers. Notwithstanding this research, teacher competencies are considered to lead teachers to work professionally under any learning circumstances. To some extent, teacher competencies are also the key to explore and comprehend people to understand more what actually "Professionalism" is. Even so, there are still a lot of employed teachers working in any educational institution unclearly. Moreover, they are possible to be professional or not depends how they see professionalism on their own perspectives.

From the explanations above, it seems that professionalism in Indonesia is whole a complex idea of how teacher can describe and determine their own concepts of professionalism. In addition, for some extent, they also have to owned teacher professionalism regulated in the Law Number 14 Year 2005. Therefore, this research is conducted to seek enlightment of teacher professionalism in Indonesia from the PSTs point of view. Further, this research uses three previous studies as the basic foundation to support the research and help to construct future theoritical framework. As for the first previous study that is used which is a thesis conducted by Utami (2015) entitlted with "A study on teachers effort in developing their professionalism at SMAN 1 Ngunut". The study revealed that teachers professionalism are actually based from four teachers competencies that is set by the Law Number 14 Year 2005. The second previous study that is used which is a thesis codcucted by Grace Ika Yuwono (2008) entitled with "Indonesian EFL Teacher Professionalism: A Case Study in Salatiga Municapility". The study found that the regulation of Indonesian Law Number 14 Year 2005 were fundamental in determining teachers' professionalism in Indonesia. While the third previous study that is used which is a dissertation conducted by Ju Huan (2017) entitled with "A Narrative Inquiry into Chinese Pre-service Teachers Education and Induction in South West China Through Cross-Cultural Teacher Development". The study showed that PSTs' perspectives are drawn into some narratives. It is made in order to show the experiences of their professional development and profession as teachers as well as their experiences of becoming beginning teachers.

This research will use the combination of Law Number 14 Year 2005 and some related studies as the basic foundation, nonetheless. Moreover, this study will involve only PSTs' perspective 
towards professionalism into a narrative inquiry research design as what recommended by the third previous study in order to unveil the hidden thoughts and experiences towards teacher professionalism in Indonesia. Furthermore, the researcher draws the following .reseach objective which is to know the perspectives of the PSTs through deep interview of the teachers' stories or experiences towards teacher professionalism.

To give a theoretical framework of professional teacher, Indonesian government issued the Law Number 14 Year 2005 which anchor all performances of teachers. Every Indonesian needs to understand the regulation, in which, especially affect their life as well as their profession. However, the definition of professional teachers is not clearly well elaborated yet as teachers have their own concept of professionalism. Numerous theories explained that there are factors that can influence and determine teacher professionalism which are teacher roles, teacher competencies and teacher professional development, which have to be internalized in order to achieve the standards of professional teachers.

Nevertheless, this research used Brown (2007) explanations as the basic theory. The researcher chose this theory because this theory are also the fundamental theory of both Archana and Rani's (2017) and Ignatius's (2017) concepts which happened to be the most accurate and applicable to condition of Indonesia, since the roles of a teacher are implicitly regulated in the Law Number 14 Year 2005. Brown (2007) explained that teachers have to able to interact more with the students. He said that the best way to interact is through interaction itself.

As professional teachers these four competencies; pedagogic, professional, personal and social competence should be mastered and integrated one to another in order to establish good teaching eventually. In line with the regulation, the concepts and explanation from Mulyasa (2007) and Wardoyo and Herdiani (2016) are used to be the basic theory and foundation to work with the teacher competencies as one of the aspects that can influence and determine the professionalism of teachers (e.g. Mulyasa, 2007; Wardoyo \& Herdiani, 2016).

To work with the regulation In Indonesia about the professionalism development, Hagreaves (2000), analyzed the development of teacher professionalism around the world is done by four phases or four ages which are: 1) The preprofessional age; 2) The age of autonomous professional ; 3) The age of collegial profession; 4) The post-professional age. Hargreaves defines today's professionalism as postmodern professionalism -a new era- marked by polarized directions including in Indonesia. In Indonesia, the term of professionalism has been very wide and people have their own standards to define professionalism of teachers.

\section{METHOD}

This research was conducted to explore and to know the perspectives from pre-service English teachers that were responding on the topic of teacher professionalism through narrative inquiry. This research also brought sub-topics that included teachers' roles, Indonesian teachers standards; related to teachers' competencies, and the teachers' professional development, that basically all of the sub-topics refers to the Indonesian Law Number 14 Year 2005, which in this research, the law is used to be the basis and the foundation of the research study Thorughout this complexity of the study, the researcher proposed to use narrativeinquiry as a research design which employed a qualitative approach. Creswell (2013) defined qualitative study as the assumption and theoretical frameworks that informed a study of a particular research problem. To support the researcher's research design, the perspective of preservice teachers were required, which the research was framed within the context of the teacher' lived experiences, Horvat (2013). 
Explicitly, this research design used narrative inquiry as the main point of the research findings that led the research to the most important result. Narrative inquiry itself is a qualitative method that is about studying stories, words, statements of people to understand their experiences in order to create a larger history, stated by Pinnegar \& Daynes (2007). Stories make individuals to explore experience as phenomenom and it is worth to study, Clandinin \& Rosiek (2007). According to Clandinin (2013), narrative inquiry is a way to understand experience through stories.

Furthermore, Clandinin (2007) explained that stories shared by participants are the stories of their lived experiences. Through deep interview, the research design that applied narrative inquiry had met enough requirements to get the subjects' experiences through their stories or experiences verbally. Therefore, in line with the theory of experience by John Dewey, the researcher aimed to see pre-service teachers perspectives in form of stories and experiences delivered verbally which was studied to gather data and would be analyzed as the concrete data that were based from their experiences.

In this research, the data were taken were in forms of statements (subjects stories and experiences delivered verbally), voice records, transcript documents of the recordings, as well the photos and videos. Furthermore, the data were taken in form of:

1) Selected Subject Interviews results (based on the subjects stories and experiences delivered verbally)

2) Selected Subject FGD results (based on the subjects stories and experiences which are discussed in the forum)

In this research, the researcher collected the data source from the subjects where there are 10 (ten) PSTs who were used as the primer data through interviews and FGD. As mentioned previously, the subjects were 10 (ten) Indonesian preservice English teacher, which are 9 (nine) of them are located in Malang, while 1 (one) of them is located in Bali. However the researcher set some criteria to the subjects as follows: Whether the participants are 1) Pre-service teachers; those teachers who are pursuing teacher professional development programs, or 2) Experienced Pre-service teachers; those teachers who had many experiences in teaching for a long period of time. Nevertheless, there were four research procedures which were: 1) Doing preliminary study, 2) Collecting data, 3) Managing data, and 4) Validating data.

This research used two instruments which were interview guidelines and FGD (Focus Group Discussion) quidelines. For the interview guidelines instrument, the researcher adopted it from a thesis research of Yuwono (2008), entitled "Indonesian EFL Teacher Professionalism: A Case Study in Salatiga Municapility" which was the research's second previous study. The researcher believed that as the previous study and its similar topic would help the researcher to use the interview guidelines wisely. Meanwhile, for the questions items of the instruments that indicating parameters of employed topics, the researcher used Wardoyo and Herdiani (2016) variable and indicator (teachers' professional developmement and competencies) in his paper research entitlted "Teacher Professionalism: Analysis of Professionalism Phases" that were used to develop questions from the topic and sub topics. While for the question that shows variable and indicator of teachers roles was using the research of Brown (2007). This was done to consider the research needs and goals.

To collect data, the researcher did two ways to gain the data that the researcher need which are the interviews and FGD, therefore the researcher were focus on how to conduct good and deep interview as follow: conducting, First Direct Interview, Second Direct Interview, Indirect Interview, Third Direct Interview, FGD (Focus Group Discussion)

In order to answer the research questions, data analysis was made in order to accomplish the purposes of the study. According to Miles \& Huberman (2007) stated that the step of analyzing the data 
which are by data reduction, data display and data verification.

The data were then used as to revealed the findings by segmenting the narrative data into themes as suggested by Creswell that narrative researcher typically present the themes or catagories after restorying or retelling the story. The themes was segmented based on the subjects experiences to elicit the pre-service English teachers past, present and future. Theme 1 was 'The Law of Holistic Teachers' which covered sub-theme; Teachers' Response on The Law No 14 Year 2005. Theme 2 was 'Main Actor or Main Factor' which covered sub-theme; Teachers' Response on Teacher Roles. Theme 3 was 'Endless Parameters' which covered sub-themes; Indonesian Teacher Standards, Teacher Competencies. Theme 4 was 'Reaching The Sky' which covered sub-themes. Professional Development Experiences, and Teachers' Reasons. Theme 5 'The End Point' which covered sub-theme; Pre-Service English Teachers Professionalism. To understand more about the data analysis, therefore the researcher display the data analaysis blueprint into the table 5 below.

The validity of the study is very important thing in a research. In qualitative research, there is common technique usually used to check the trustworthiness of the data. In qualitative research there are some techniques that can be used to make the research data valid. Bogdan \& Bicklen (1998) stated "Triangulation is used to convey the idea to establish a fact that needs more than one source of information" (Bodgan \& Bicklen, 1998, p. 101).

\section{RESULTS AND DISCUSSION}

This part highlights the important results of the participants' interviews and FGD. Important experiences are represented by the PSTs towards their perspectives of the teacher professionalism. The stories and the experiences shared verbally by the PSTs are genuine. Further, theoritical framework are employed to see the right flow of the research.
To work with the flow of employed theoritical framework, the research are segmented into several themes in order to answer the research question. Therefore, to know the PSTs perspectives towards teacher professionalism, the findings of the research study are explained based on the followings emloyed themes.

\section{Theme 1: The Law of Holistic Teacher}

Since the research is focus on teacher professionalism especially in Indonesia, teacher professionalism in Indonesia is basically regulated in the Law Number 14 Year 2005. The law regulates about teacher professionalism related with the changes of Akta 4 terms into teaching certificate that will be only provided by the professional development program called PPG. The theme itself tells about what are the prespectives of PSTs toward the regulation. The finding also shows different responds on the regulation that eventually brings suggestion and comments towards the regulation itself.

\section{Theme 2: Main Actor or Main Factor}

Related to the regulation set by the Law Number 14 Year 2005, teacher roles are mentioned as the main function of teachers that should be reflected into their teacher professionalism. The theme itself tells what are the perspectives of PSTs towards the teacher roles as a possible factor that can influence teacher professionalism. However, the findings show that the PSTs are well-known about teacher roles. Moreover, their perspectives towards the teacher roles show that teacher roles can determine teacher professionalism, but somehow, it does not directly determine the professionalism, rather than as a supporting aspect that teacher should have while teaching.

Most of PSTs explained that teacher roles can be one of the factors that inluence teacher professionalism, but it can not be the main factor. As PST10 kept emphasizing that teacher always have to improve themselves, so then their 
professionalism as a teacher will improve as well.

'... But if you just keep teaching,
teaching and teaching... do not
think beyond the classroom,
and that way, your
professionalism will stop. If you
gain the score in your certificate,
7 (seven) for example, that's
your score, will not improving.
But if you keep improving
yourself. See that the student
can give you something more
than just teaching and learning
process, that thing will give you
9 (nine), or even 10 (ten). I
experience that one.' (PST10)

Further, PST10 corrected that the improvement is related with the teacher competencies. As the result of FGD, most of the PSTs changed their perspectives towards teacher roles at the end of the day. They mostly agreed that teacher roles is not the most dominant factor that can influence teacher professionalism rather than be supportive aspects that deploy teacher competencies as the standards of teacher professionalism in Indonesia.

\section{Theme 3: Endless Parameters}

Most of PSTs exposed that teacher roles is basically a part of teacher competencies that can not be separated from the application itself. This theme employs a notion of the PSTs' perspectives towards the teacher competencies as the most dominant factor that can influence teacher professionalism. The findings reveal that the PSTs had known what the competencies of teachers are. They know it prior to the knowledge they got while they were pursuing study in their the undergraduated program, postgraduated program. In addition, the other PSTs even know it while they are pursuing study in their PD program.

PSTs' perspectives towards the teacher competencies reveal that teacher competencies can be the main factor that determine teacher professionalism. Many of them thought that teacher competencies are an obligation for a teacher. They also reveled that teacher competencies is the most crucial aspect that teachers must have in order to make themselves as professional teachers, yet not to mention as professional English teachers.

Eventually, most of the PSTs thought that teacher competencies is the most important aspects towards teacher professionalism. In addition, PST10 corrected that by acquiring teacher competencies and reflecting it towards teacher roles is not enough yet to determine and own teacher professionalim. Thus PST10 recommended teachers to join PD program to become official professional teachers.

'... But again, you didn't get any certificate from the government because you didn't join any PPG, it's not good enough. ...' (PST10)

'... Everyone who wish to be professional must join PPG, that's the thing. ...' (PST10)

According to the findings acquired from all of the PSTs' stories and experiences, as the result of FGD, most of the PSTd agreeed that teacher competencies is the most dominant factor that can determine teacher professionalism. They thought that teacher competencies are the fundamental aspect tn constructing the teacher professionalism. Nevertheless, PSTs explained that teacher competencies can be acquired, developed and implemented while and after joining the PD program.

\section{Theme 4: Reaching the Sky}

According to the PSTs' narratives exposed that their experiences and journey while pursuing study in PD program called PPG program are different and unique one to another. This theme reveals the PSTs perspectives towards the professional development program especially in Indonesia as a factor that can influence and determine teacher professionalism. These findings show that PD program is very 
important. As the most of PSTs intends to join the PD program to own their teacher professionalism. Meanwhile, some of them explained that PD program gives a chance for teacher to create their professionalism rather than taking their professionalism. Nevertheless, PSTs of non PD program students reveal that they are indeed interested to join PPG program or any PD program to own what is called as teacher professionalism.

It is found that there are different impacts and reasons of the PSTs taking the PPG program, nonetheless. Similarly, PSTs of non PD program students who are interested taking PPG program reveal different impacts and reasons. The PSTs thought that by joining PPG program they can shape their professionalism. Yet, the PSTs also thought that the reason of joining PPG program is to get better salary. Eventually, they explained that being a teacher without professional teacher certificate provided by PPG program, thus will not give enough money and satisfying salary.

In these findings, there are two perspectives revealed from different PSTs. The first perspectives are from the PSTs who had joined PPG program since 2018 and the other are from the PSTs who have not joined the PPG program yet, instead of taking study in post-graduated program. In addition, a perspective from one PST who has not taken any PPG as well as postgraduated program but has many experiences in teaching.

\section{Theme 5: The End Point}

This last theme entitled "The End Point" is mainly what inspired the researcher to conduct this research. The theme highlights the most important findings to answer the research question which is PSTs' perspectives towards teacher professionalism. In this part, in fact, the findings mostly reveal the PSTs' perspectives towards teacher professionalism different one to another.

In this important part, the PSTs reveal how they truly see teacher as profession especially in Indonesia. They also reveal how they describe a professional teacher, and thus teachers own teacher professionalism. However, this theme mostly points out PSTs' own concepts of professionalism when they are asked how professional they are and how they could describe their teacher professionalsim after all.

\section{"When you want get the beauty of the rose, you must get through the pain of the rose first instead" $-\boldsymbol{A} \boldsymbol{G}$}

\section{The Discussion: The Pre-Service Teachers' Reflection}

This part highlights important reflection and the interconnection to some relevant theoritical and empirical evidences. As this research employed narrative inquiry, the experiences and stories from PSTs towards teacher professionalism will be discussed into the related segments of the employed themes. However, identifying important experiences were based on the nature of this research. Moreover, the experiences were analyzed whether the perspectives of PSTs indicate theoritical and empirical evidence that can be used to acknowledge readers to understand more about teacher professionalism especially in Indonesia.

Therefore, in this part the researcher will discuss more about the regulation of the Indonesian Law Number 14 Year 2005, teacher roles, teacher competencies, teacher professional development theories, and teacher professionalism eventually. Nevertheles, the most important in this research definitely comes from the PSTs perspectives towards teacher professionalism in form of their narration, stories and experiences which is valued to be fruitful and genuine since the reasearch deployed narrative inquiry research design as the main focus of this research.

\section{The Law of Holistic Teacher}

Bringing topic of teacher professionalism waking the researcher and the PSTs up that this topic is actually very wide, yet can not 
be described simply. Since teacher professionalism in Indonesia is explicitly regulated in the Law Number 14 Year 2005. The law mainly points out some important parts which are: 1) Teacher and Lecturers which mainly discussed the teacher description and teacher roles, 2) Teacher Qualification which mainly discussed teacher standards, 3) Teacher Competencies, 4) Teaching Certificate, and eventually 5) Teacher Professionalism that generate the idea of professional teacher, and Indonesian teacher professionalism as well.

As the research found several facts that revealed many PSTs' narratives which showing that the law regulating teacher professionalism is actually good. However, PSTs thought that the implementation of the regulation is no longer suitable to the condition of teacher professionalism nowadays due to many changes, therefore it needs government action to fix and adjust the regulation so then the implementation can achieve its goals.

\section{Main Actor or Main Factor}

An essential part, being professional teacher is that when teachers can apply their professionalism inside and outside classroom and school. When talking about teacher professionalism in the classroom is atually talking aslo about those teachers who are able to apply several professional roles to conduct good teaching and learning. To be able to implement teacher professionalism in the classroom, teacher have to know their roles and thier function clearly. According to the regulation of the Indonesian Law Number 14 Year 2005, in the act 1 (one) explained that teacher is a professional educator whose key tasks are to educate, guide, direct, train, value, and evaluate students. The explanation shows that teacher as professional profession have many roles in a classroom, yet not to mention the roles of teacher in a school.

Teacher roles in the classroom is not like how people understand a long time ago that teacher used to be just a person that only give students learning materials and tasks to do in order to accomplish their education. Teacher roles nowaday plays is more than what we used to know, it has many certain important roles as what Brown (2000) described that the roles of interactive teachers in the course of teaching is the same roles of parents. Brown (2000) furthur explained that teacher playing many roles is that teacher can implement both directive and indirective roles.

\section{Endless Parameters}

In the world of teacher professionalism, teacher competencies is the most important factor that teachers have to have in order to acquire their professionalism. According to the regulation of the Law Number 14 Year 2005 in the act 10 (ten) explained that teacher must have teacher competencies that consist of pedagogical, personal, social and professional competencies. Towards the findings, not all of PSTs understand and well-known teacher competencies even those PSTs who have already taught in the school before for several times. Thus, it needs more attention towards teachers to understand well teacher competencies, since it is very important for them as indicators of having teacher professionalism.

Each individual teacher competencies can not be acquired separately. To implement good teacher professionalism, the four competencies should be acquired and developed once and at the same time. According to Mulyasa (2007) teacher competencies should be engaged in every teaching and learning activity. Thus teacher competencies shows whether teachers have the teacher professionalism or not. To understand more teacher competencies, Mulyasa (2007) explained each competencies vividly. As he explained that teachers who have pedagogical competence is that teachers who can understand students, manage, plan, implement, using technology and evaluate good learning. The explanation points out how teachers can cooperate side by side with their roles of teacher in order 
to develop their pedagogical competence in the classroom. While in the context of professional English teachers, thus teachers have to master also some particular English skills like teachers have to master the basic skills in reading, speaking, listening and writing, as well grammars. These points should be cooperated once PSTs want to be a professional English teacher (Mulyasa, 2007).

\section{Reaching the Sky}

This part highlights the discussion of the research considered the participants of the research which are PSTs that have different background of study towards their perspective on PD program that is PPG program. From the stories of the PSTs, most of them thought that to acquire teacher professionalism is a must for teachers to have the teaching certificate representing their teacher professionalism. The certificate itself is given for those teachers that have passed the PPG program whose purposes and goals attached in the regulation of the Indonesian Law Number 14 Year 2005 as the only program that government provided to give the certificate of professionalism. Therefore, throughout this discussion, PSTs believed that PD program which is PPG program is very important to them in order to get their teacher professionalism.

To work with teacher professionalism, in this discussion there two perspectives from two different background. The first is the perspectives from the PSTs who had joined the PPG program, and the second is the perspective from the PSTs who have not joined the PPG program yet. The result were revealing that both PSTs have similarities, and some slight distinctive perspectives.

\section{The End Point}

At the end of the interviews, all of PSTs were asked about the last thing that is what exactly their professionalism are, and how they describe their professionalism. Yet to some extend, they show their reality of becoming teachers which happened to be different in every situations and condition they face. Their perspectives towards teacher professionalism show how they thought about teacher as profession, the rewards of being a teachers, and eventually their reasons of becoming teachers. Furthermore, they also describe how their professionalism is, how professional they are as a teacher and the position of teacher professionalism in Indonesia.

From the stories, when the PSTs were asked about their perspective towards the condition and situation of teachers as profession nowadays in Indonesia, most of them thought that teachers condition are still not yet good. PSTs stated that work as teacher is challenging but at the same time is also fun and worth to have. They thought that being teacher is easy, and many people probably think the same way.

When PSTs are asked whether they want to be a teacher or not in the future, few of them told that if just they can take back the time, they will look forward to another profession. It means, that not all of teachers can survive with the profession of a teacher. One of the consideration of most PSTs is that when PSTs have not yet gotten a chance to continue their study in PPG program or pass the final examination of PPG program itslef, they are afraid that becoming and sticking to the statues of honory teachers will make them waste their time, as the payment is not suitable to what they do for their profession as a teacher. Moreover, students and schools will be always demanding more compatible and more professinal teacher.

However, there are few people who do not expect so much towards salary or money, a part from that, PSTs revealed that their reason of becoming teacher is simply by making other people, especially students to feel happy or to know something new, and thus is something that can make teachers relief that as humans they can give something and share something they have. Moreover, the PSTs' reason becoming teacher is basically because they think that teacher as profession is noble and full of merits. 
Furthermore, mostly when PSTs were asked whether they can describe themselves as professional teacher or not, they answered doubtly and hestitate to answer that they all are professional teachers. Since they thought that teachers can not satisfy for what they have now, but rather to be satisfied for what they will have later. This make one thing really interesting that is one of the PSTs kept pointing out and keep emphasizing things that teachers have to always improve themselves. Once they have the professionalism, they still can not be satisfied, yet they always have to learn and need to learn, yet take every opportunity to learn and improve themselves as better professional teachers.

Eventually, the only things that PSTs thought can determine whether they are professional teacher and whether they already have the teacher professionalism is by acquiring the certificiate through PPG program. Therefore, by acquiring the certificate, thus teachers will be called as professional and have that teacher professionalism. Moreover, towards the PSTs' stories and experiences found out that they reflects the age of professionalism in Indonesia is already in the level and position or phrase of post-professinal since professionalism in Indonesia on their eyes are complicated and hard to be described (Hargreaves, 2000).

Lastly, the most interesting things to be discussed is that most PSTs draw and describe themselves as professional teachers of their versions. Standards that are made by the government is something that makes them believe to be followed, but however, as since they are the one who can make a way and choose the appropriate way for them to achieve the professionalism of teachers makes them independent individuals to make their own concept of professionalism. Nevertheless, their concepts are still in the similar and right tracks with what is existed. As what stated by the PST10 that his standards of being professional teachers and to have what is called as professionalism of teacher, he delivers the term in Indonesia which again deliver message to all teachers that they have to always improve themselves in order to be better teachers.

'Do not just stop when someone judge you 'You good', and you just stop, it is not good. Do not be, in Bahasa Indonesia we call it 'Katak

Dalam Tempurung'No! Never!' $-H Y$

\section{CONCLUSION}

Conducting the presents study on preservice English teachers towards teacher professionalism shows the dynamic shanges of the experiences. This study opens how teacher professionalism is seen by particular people and thus people who are envolving themselves into the teacher professionalism. Throughout truthful stories and experiences delivered by PSTs, it guides the researcher to draw and form the research into voices of teachers who have thoughts and different perspectives towards teacher professionalism. These meaningful voices can make people, teachers and government realize and open their eyes that the word of teacher professionalism is not just a simple phrase but complex, and shopisticated words that can make a change towards teacher as profession. Eventually through the study, the researcher found several findings towards the teacher professionalism.

The first finding reveals that the regulation of the Indonesian Law Number 14 Year 2005 which regulates teacher professionalism still does not reflect the contents of the regulation. With all things being regulated, teachers and governments need to cooperate and constribute in the process of making and deciding the most suitable regulation that both parties can accept. A part of the regulation's contents, implementation is the most important thing that should be done correctly since what has been made in the regulation should be implemented in the real life. As stated in the regulation also, teachers may have obligation due to the regulation as well their rights in doing their profession. These rights and obligation is the a must for 
teacher to make them keep compromising and doing their profession as it should and keep the right track on doing so. Nevertheless, teachers also need to use their rights and obligation of becoming teacher properly and wisely, thus the regulation will also work perfectly.

The second finding reveals that teacher roles can help teachers to implement their professionalism. To reflect their professionalism as teachers, a professional teacher have to be able to employ several important roles that can be implemented in every condition. In regards, students are also the most cruicial things to be considered that teacher roles can reflected inside and outside the classroom. However, teacher roles can be as much important as teacher professionalism if teachers apply the roles wisely. This is proven by the most PSTs' statements that offer teacher roles as the only way to reflect their professionalism in the classroom and in the schools. Thus teachers need the abality to utilize, use, manage and maintain their roles continously in order to avoid any possible mistakes on showing the roles of teachers in particular situation and condition (Borwn, 2007).

The third finding reveals that teacher competencies are considered as the main factor that can determine and influence teacher professionalism. Teachers have to have the four competencies which are pedagogical, social, personal and professional comeptence at once. As professional teachers, they need to have teacher competencies completely, and all the competencies have to be outstanding, and complement one to another. Moreover, teacher competence can be implemented through the roles of teacher in the classrom. The teachers should use teacher roles as the way to reflect and implement the teacher competencies in the classroom and inside the schools. However in order to acquire teacher competencies, the only explicit way to acquire the competencies is that teachers need to join any professional development in order to get, develop and mantain more whether the competencies that they have or competencies that they still try to develop slowly.

The fourth finding reveals that professional development is very important for teachers to get the teacher professionalism. Professional development in Indonesia such as PPG (Pendidikan Profesi Guru) is a must for teachers if they want to deserve called as professional teacher and want to get the certificate of professionalism or teaching certificate that can be used for the future of the teachers, and give bennefits for them as well. The certificate is unfortunately is the only way to make the teachers called as professional teacher thus they will have what is called as teacher professioanlism regardless their commpetencies for being teacher had been developed away before joining any professional development program. Moreoever in Indonesia, the term of teacher professionalism is only defined simply by getting the certificate, but somehow the throug PSTs' stories explained that the certificate is only thing that is writen and not the thing that is reflected. Therefore, teachers who are enrolled themselves in the PD program should put their best enthuasiasm and efforts in developing their professionalism. Thus the purpose of PD program in Indonesia will eventually meet its end. However, it is sad that the only way to find out whether teacher have the professionalism or not is by enrolling themselves in the PPG programs but since the enrollment of the program is limited, it will give disadvantages towards teachers. Therefore, it needs more attention from the government. The government needs to provide more professional development programs for teachers to give more chances for the teachers to have their professionalism.

The last finding concludes the perspectives of pre-service English teachers towards teacher professionalism. The finding covers that the reason people becoming teacher is that because they thought that teacher as profession is easy, but in the reality it is not. Teacher should 
know every aspect of teacher as profession that really important for them. That is included how ready they are to be teachers. The readiness itself is reflected on how teachers can provide and create good and professional teaching and not yet to mention their professionalism considering their roles as teachers, their teacher competencies, and their experiences in teaching have to be somewhat beyond their capability. It means that teachers have to always improve themselves to be better teachers thus teacher will be more professional than before and thus teacher will have and implement what is called as teacher professionalism. However, the low payment of becoming teachers who have not gained the professionalism certifiacte from PD program will make them hard to suvive with other profession. As mentioned before, that the attention of government towards teacher as profession still need improvement. Moreover, teachers thought that teacher professionalism is complex, it can be anything for them. Every teacher have their own standards of professionalism, but the thing that is similar one to another is that however teachers try to be professional if they have not acquired the certificate yet, they will not be able to deserved the title of professional teacher.

Conducting a narrative study results in two contribution. The first is that theoritical implication and the second pedagogical implication. The implications however are derived from the findings of this study. The main theoritical implication is to confirm whether throughout the process of getting and gaining the PSTs' perspectives from interviews and many things will expose the similar ideas towards the existed theories of teacher roles, teacher competencies and professional developments. It is strengthen by the evidences that PSTs voicing the theories implication explicitly and implicitly showing that the theories are actually implemented in their life. Throughout the findings, teacher professionalism employs teacher roles, teacher competencies and teacher professional development at once in different way which happened to be challenge of the teachers to have their teacher professionalism.

From a pedagogical point of view, the findings of this study provide some evidences of Indonesian teachers perspectives towards teacher professionalism. The evidences are more pratical which is found that most PSTs develop their professionalism rather than get their professionalism instantly. Throughout the PD program implicature, PSTs found it to be the only way to develop their professionalism by envolving teacher roles and teacher competencies to be the main course for them to always develop and maintain their professionalism. The present research findings will also fill the gap on how PSTs point out the most crucial factor that causes teacher professionalism is changed and also how they can describe and see teacher professionalism in Indonesia widely and differently.

\section{REFERENCES}

Archana, S., \& Rani, K. U. (2017). Role of a teacher in English language teaching (ELT). International Journal of Educational Science and Research (IJESR), 7(1), 1-4.

Brown, H.D. (2000). Principles of language learning and teaching (Vol. 4). New York: Longman.

------(2007). Teaching by Principles An Interactive Approach to Language Pedagogy. San Francisco.

Clandinin, D.J. (2013). Engaging in Narrative Inquiry. SAGE Publication Inc.

Clandinin, D.J., \& Rosiek, J. (2007). Mapping a Landscape of Narrative Inquiry: Borderland Spaces and Tensions. SAGE Publication Inc.

Creswell, J.W. (2013). Qualitative Inquiry \& Research Design Choosing Five Approaches. SAGE Publication Inc.

David, A.G.B., \& Lisa, F.S. (2014). PreService Teachers'Efficacy Beliefs and Concers in Malaysia, England, and New Zealand: Issues in Educational Research 24(1). 
Jurnal Pendidikan Bahasa dan Sastra, Volume 20, Nomor 1, April 2020, pp. 95-110

Hargreaves, A. (2000). Four Ages of Professionalism and Professional Learning: Teachers and Teaching: History and Practices.

Horvat, E. (2013). The Beginner's Guide to Doing Qualitative Research: How to Get into the Field, Collect Data, and Write Up your Project. Teachers College Press.

Kukari, J. A., \& Ogoba, E. (2001). Preservice teachers' preconceptions of curriculum: How they evolved and are evolving as a result of teacher education experiences. Papua New Guinea Journal of Teacher Education, 2(1), 10-25.

Mulyasa, E. (2007). Standar Kompetensi dan Sertifikasi Guru. Remaja Rosdakarya.

Pinnegar, S., \& Daynes, J.G. (2007). Locating Narrative Inquiry Historically: Thematics in Turn to Narrative. Sage Publication

Utami, H. (2015). A Study on Teachers' Efforts in Developing Their Professionnalism at SMAN 01 Ngunut. Thesis. Indonesia

Wardoyo, C., \& Herdiani, A. (2016). Teacher Professionalism: Analysis of Professionalism Phases. International Education Studies, 10(4), 90-100.

Yuwono, G.I. (2008). Indonesian EFL Teacher Professionalism: A Case Study In Salatiga Municipality. Thesis. Sydney. 